Lars Risan og Siri Nфrve

\title{
Universell utforming og den vanskelige avgrensingen av «alle»
}

\begin{abstract}
Sammendrag
Universell utforming er et prinsipp hvor målsetningen er at «utforming av produkter og omgivelser [skal skje] på en slik måte at de kan brukes av alle mennesker, $i$ så stor utstrekning som mulig, uten behov for tilpassing og en spesiell utforming.» (Aslaksen mfl, 1997, den forste norske definisjonen) I lopet av de siste 15 årene har dette prinsippet blitt fremmet $i$ Norge som et utvetydig fremskritt. Det kan imidlertid vare farlig å tro at en ren teknisk lфsning kan bygge bro over politiske kontroverser (Imrie 2012), og i denne artikkelen vil vi vise hvordan viktige ideologiske premisser er skjult under paraplyen om universalitet. Vårt empiriske felt er norsk boligpolitikk fra etterkrigstiden og fram til i dag. Innenfor dette feltet ser vi at det har vort argumentert for ulike versjoner av «universell utforming» de siste 40 årene, selv om navnet «universell utforming» er av nyere dato. Vi vil vise hvordan prinsippet har endret seg fra å ha et sosialdemokratisk innhold - før det ble omdøpt til «universell utforming»-for å bli inkorporert i et nyliberalt boligpolitisk paradigme de siste 15 årene. De sosialdemokratiske forgjengerne til «universell utforming» ble til dels formulert som videreutviklinger av en boligpolitikk for sosial rettferdighet og $\phi$ konomisk likhet. Med innføringen av begrepet «universell utforming» har denne brede sosiale rammen forsvunnet, men under dekke av universalitet og entydig framskrittsoptimisme har denne politiske endringen blitt underkommunisert. ${ }^{1}$
\end{abstract}

Stikkord: universell utforming, sosialdemokratisk boligpolitikk, Carsten Boysen, Byggforsk, TEK 10

\section{Innledning}

Grunntesen bak det designprinsippet som de siste årene har blitt kjent som «universell utforming» er at fysiske miljøer skal utformes slik at «hovedløsningen» i størst mulig grad skal kunne tas i bruk av «alle». Det vanligste eksempelet på hva dette innebærer er inngangsdøren til et hus: Hvis en rullestolbruker er henvist til en sideinngang så anses dette som en stigmatiserende særløsning. Rullestolbrukeren skal kunne rulle inn hovedinngangen, som «alle andre», og for egen hjelp. «Planlegging for alle» brukes ofte synonymt med «universell utforming» (Miljøverndepartementet 1998), og tanken er at hvis man planlegger for alle fra første stund, vil det som før var «spesialtilpasninger» for noen brukergrupper bli integrert i standardløsningen.

Denne artikkelen befatter seg med to sentrale og relaterte problemstillinger rundt begrepet «universell utforming». For det første er universell utforming et generelt begrep som må konkretiseres for å bli politisk eller praktisk virksomt. I en juridisk avklaring argumenterer Nicolai V. Skjerdal for at begrepet bør forstås som en overordnet rettslig standard, som til enhver tid må gis et konkret innhold (NOU 2005a, vedlegg 1). Det er allment akseptert at for enhver slik konkretisering vil man måtte ta noen pragmatiske valg. Man kan ikke tilrettelegge alt for absolutt alle. $\AA$ planlegge «for alle» har blant annet noen gjensidig utelukkende grenser. Noen svaksynte er lysømfintlige og trenger dus belysning, andre svaksynte trenger mye lys, for å maksimere kontraster (Nersveen 2009). Noen krav og behov er gjensidig utelukkende, og i definisjonen av «universell utforming» heter det også at man skal planlegge for alle «i størst mulig grad» (Aslaksen mfl. 1997). Første spørsmål er derved: Hva skjer med «universell utforming» når det oversettes fra et allment prinsipp til ulike konkretiseringer?

For det andre har «universell utforming», både i Norge og i land vi gjerne 
sammenligner oss med (Nord-Amerika og Nord-Europa), i stor grad blitt lansert som en pragmatisk, teknologisk strategi for å nå et normativt likestillingsspørsmål: Man kan, tilsynelatende, bygge eller designe seg ut av enkelte typer stigmatisering og diskriminering, og når et universelt design først blir masseprodusert, så vil dette designet i mange tilfeller være like rimelig som den gamle forskjellskapende løsningen. Ved henvisning til egen erfaring i New York City, viser imidlertid Jean Ryan at selv om en teknologi kan være «universelt utformet», vil bruken av teknologien likevel kunne virke stigmatiserende eller ekskluderende (Ryan 2006). Flere forskere påpeker at den rendyrkede troen på teknologisk design dekker over det faktum at det ligger politisk-ideologiske premisser til grunn for ideen om «universell utforming», og at vi trenger å gjøre disse eksplisitte, for å unngå den fallgruven det er å tro at design i seg selv kan være en fullverdig løsning (Findeli 2001; Imrie 2012). Vi trenger, skriver Rob Imrie, å komme oss forbi en forståelse av universell utforming som en verdinøytral teknikk (Imrie 2012, 887).

Med vårt andre spørsmål følger vi Imrie i hans påstand om at «universell utforming» er basert på politisk-ideologiske premisser som ikke alltid er like tydelige, og spør hva slags ideologiske premisser som ligger implisitt i prinsippet «universell utforming»? Men heller enn å lete etter de premissene som er felles for «vesten», slik Imrie gjør, vil vi se etter de premissene som er spesifikt norske, ja som til og med varierer innenfor en norsk kontekst. Vi vil følge noen sentrale ideologiske premisser som har virket, og fortsatt virker, innenfor en norsk politisk sammenheng.

Et slikt fokus er i stor grad informert av følgende empiriske funn: I Norge har «universell utforming» sine forløpere innenfor bygg-, bolig-, og arealplanleggingen, før prinsippet fikk navnet «universell utforming», og det å «planlegge for alle» er noe mange både har argumentert for og til dels praktisert i Norge i mer enn 40 år. Vi skal gå historisk til verks og se på ulike ideologisk-politiske prinsipper som ligger bak ulike versjoner av «planlegging for alle». Disse generelle premissene vil vi så se $\mathrm{i}$ forhold til hvordan man har forsøkt å gi dem konkret, politisk eller regulatorisk innhold, slik Skjerdal understreker at man må gjøre.

For å begrepsfeste transformasjonen fra et ideologisk eller prinsipielt «alle» til implementeringen av et mer konkret «alle» vil vi bruke formuleringene generelt alle og konkret alle. Manneråkutvalgets allmenne ambisjon om universell utforming uttrykker, overordnet, et generelt alle. Implementeringen av konkrete byggdetaljer i den siste byggtekniske forskriften (TEK 10) uttrykker et konkret alle. Det konkrete alle vil med nødvendighet innebære en pragmatisk innsnevring av det generelle alle. Manneråkutvalget var selvfølgelig klar over at universell utforming for «alle» ikke vil kunne nå absolutt alle, og de problematiserer på mange måter de pragmatiske såvel som prinsipielle utfordringene med integrering og normalisering (se f.eks. NOU 2001, 32-33). Men de tar ikke de konkrete valgene som i praksis blir knesatt gjennom TEK 10. Det vi mener med en overgang eller implementering fra det generelle til det konkrete vil i noen tilfeller bestå i en begrepsmessig konkretisering og fagliggjøring, $i$ andre tilfeller en overgang fra intensjoner til en politisk strategi.

Måten «planlegging for alle» både formuleres som et generelt alle og et konkret alle gir oss et inntak til å forstå det spesifikt politisk-ideologiske innholdet i ulike versjoner av «universell utforming», og en historisk gjennomgang av slike ulike versjoner gir oss det komparative blikket vi trenger for å kunne vise at dagens versjon av «universell utforming» ikke er den eneste mulige måten å formulere en politikk som søker å bygge ned stigmatisering og diskriminering ved å «planlegge for alle».

Vi fokuserer på boligfeltet, og gjør det av to grunner: for det første fordi vi hadde mandat til å studere boligfeltet, gjennom et forskningsprosjekt finansiert av Husbanken, og fordi innholdet til den norske versjonen av «universell utforming» i stor grad ble hentet fra 
husbankens standarder, norske byggforskrifter og norsk byggforskning. Det er viktig å vise at universell utforming faktisk har en forhistorie, fordi det gir oss mulighet til å stille spørsmål ved hvorvidt den nåværende versjonen av prinsippet er den beste versjonen, eller i det minste ved å vise at den i hvert fall ikke er den eneste versjonen.

\section{Fra velferdspolitikk til reguleringspolitikk?}

I sin populærvitenskapelige historiebok om funksjonshemning beskriver Jan Tøssebro introduksjonen av «universell utforming», fra midten av 1990-tallet og utover, som en vending fra den nordiske velferdsmodellen til den amerikanske reguleringsmodellen. Man begynte å «se til USA», skriver Tøssebro (Tøssebro 2010, 112), og noe av det man oppdaget var «universal design», som man oversatte til norsk. Tøssebro illustrerer vendingen med et sitat fra rullestolbruker og tidligere miljøvernminister Guro Fjellanger. Sitatet gir oss en kortfattet illustrasjon av to ulike politiske regimer:

I Norge er det ikke noe problem å få rullestol, utfordringen er å komme fram med den. I USA går det bra å komme seg fram med en rullestol, men det er ikke gitt at du har råd til å skaffe deg en. (Fjellanger i Tøssebro 2010, 108)

Den amerikanske versjonen av «universell utforming», universal design, har en lang forhistorie i USA. Allerede i 1961 begynte man å etablere standarder for «barrierefrie» bygninger i USA, etter press fra krigsveteranenes organisasjon, og etter en serie lover utover 1970- og 1980-tallet kom den mest omfattende loven i 1990, kjent som The Americans with Disabilities Act of 1990. Amerikanske forskere har også vært viktige for feltet, fra Lewis Mumfords «housing for the elderly» (Mumford 1956) til Edward Steinfelds arbeid med «universal design» (Connell mfl. 1997; Steinfeld and Maisel 2012).

Den norske ordsammenstillingen «universell utforming» er inspirert av den amerikanske tradisjonen. I perioden 1995 til 1998 jobber bygningsingeniøren Olav Rand Bringa for Rådet for funksjonshemming med et mandat om å lage informasjonsmateriell for «tilgjengelighet». Han samler det han finner i de to dokumentene Universell utforming. Planlegging og design for alle (Aslaksen mfl. 1997) og Veiviser til universell utforming (Bringa 1998). Bringa lanserer begrepet «universell utforming» som en oversettelse av «universal design», og tilfører derved det norske språket noe helt nytt. «Universell utforming» gir null treff før 1998 i avisens Retriever.no, som for VGs del går tilbake til 1948, og i intervju med oss forteller Bringa at han var på jakt etter en ny frase, og at han sjekket med Språkrådet at ordsammenstillingen var ny.

Når så Manneråkutvalget hevder at «universell utforming» ble hentet fra USA på slutten av 1990-tallet (NOU 2001, 14-15), og slår fast at «man ikke [har] lagt universell utforming til grunn ved utforming av boliger og boområder» (NOU 2001, 202), så er det lett å gi dem litt rett. Det er også lett å gi Tøssebro litt rett i at man begynte å «se til USA» en gang på 1990-tallet.

Vi vil heller ikke bestride Tøssebros argumenter for at arkitektur og offentlige rom var og er bedre universelt tilrettelagt i USA enn i Norge (Tøssebro 2010).

Det er imidlertid flere grunner til å sette spørsmålstegn ved det historiske skillet som Tøssebro reiser mellom en velferdspolitisk og en reguleringspolitisk periode, som da også sammenfaller med tiden før og etter at «universell utforming» ble lansert. Det er, for det første, noe problematisk ved selve ordet «reguleringspolitikk», for det er klart at Norge har drevet politikk gjennom reguleringer lenge før man oversatte «universal design» til norsk, noe Tøssebro også problematiserer (Tøssebro 2010, 110).

Det viktigste problemet med det historiske skillet som Tøssebro (og til dels Manneråkutvalget) trekker, er imidlertid at tiden før og etter lanseringen av begrepet 
«universell utforming» i liten grad lar seg karakterisere av Guro Fjellangers spissformulering. Det finnes viktige historiske kontinuiteter som gjør det problematisk å skrive som Manneråkutvalget gjør, nemlig at man før 2001 «ikke [har] lagt universell utforming til grunn ved utforming av boliger og boområder». Det finnes også brudd som gjør at man ikke kan karakterisere universell utforming som et uproblematisk tillegg (hentet fra Amerika) til en etablert og eksisterende norsk velferdspolitikk, slik Tøssebro gjør. Det vi i det følgende skal gjøre kan derved oppsummeres i tre enkle kulepunkter:

- Bedre forstå perioden før universell utforming. Vi vil kalle dette tiden for sosialdemokratisk planlegging for alle.

- Bedre forstå hva universell utforming har utviklet seg til å bli. Vi vil kalle dette tiden for reguleringspolitisk planlegging for alle.

- Sammenligne de to periodene, for å bli bedre i stand til å se hva som er vunnet og hva som er tapt.

\section{«Planlegging for alle» som et sosialdemokratisk «generelt alle»}

Rådet for funksjonshemming og Olav Rand Bringa så til USA når det gjaldt å finne begrepet «universell utforming», samt dets allmenne definisjon. Imidlertid er alt konkret innhold i de to første dokumentene som definerte «universell utforming» nesten utelukkende hentet fra norsk byggforskning og «byggaktivisme» (Aslaksen mfl. 1997; Bringa 1998). Referansene går til Byggforsk sine byggforskblader, norske byggforskrifter (TEK 87 og TEK 97), og informasjonsmateriell fra interesseorganisasjoner som Blindeforbundet og Norges Handikapforbund. Dokumentene er rikt illustrert med bilder av allerede bygde boliger og utemiljøer - alle fra Norge - som er utformet med god tilgjengelighet og brukbarhet.

Når vi så går videre inn $\mathrm{i}$ den tradisjonen som Bringa referer til, ser vi at norsk byggforskning opererte med versjoner av «universell utforming» lenge før prinsippet fikk dette navnet. Disse ideene ble i stor grad utformet av det som het uføregruppa ved Norges Byggforskningsinstitutt (NBI) (Guttu 2003, 364). Dette var en gruppe som igjen leverte viktige premisser til Handikapforbundets «livsløpsbolig», fra 1981. Livsløpsboligen (både som prinsipp og som bygde eksempler) var i sin tur en sentral inspirasjonskilde for Bringa, når han utformet prinsippet «universell utforming». Det var ikke minst fordi Bringa også var med å utforme livsløpsboligen som prinsipp (Seierstad, Jacobsen, og Bringa 1981).

På 1970-tallet var arkitekten Carsten Boysen uføregruppas ubestridte leder og inspirator. På 1970-tallet skrev han blant annet om det han kalte «planlegging for alle» (Boysen, Hansen, and Lange 1974), på måter som er nesten identisk med dagens tanker om universell utforming ${ }^{2}$. Vi skal derfor begynne historien med Boysen, og kort gjøre rede for den første artikkelen hvor han presenterer argumenter og forskning som senere skal bli sentrale for «uførgruppa». Artikkelen er fra 1964 og har tittelen Boliger for eldre Spesialboliger eller høynet boligstandard (Boysen 1964).

\section{Boysens «Boliger for eldre»}

I denne artikkelen er Boysens viktigste overordnede grep å skrive om «uførhet» ved å fokusere på eldre mennesker. Derved har han et fokus hvor grensen mellom de «normale» og de «uføre» blir uklar, fordi de fleste mennesker som blir gamle også blir «uføre», i større eller mindre grad. I den første halvparten av artikkelen fokuserer han på det konkrete; på ulike former for svekkelse (svaksynthet, dårlig hørsel og syn, bevegelseshemminger, glemsel) og på hva som byggteknisk kan gjøres for å møte disse svekkelsene.

I den andre halvparten av artikkelen løfter Boysen blikket og ser mer sosiologisk på hvordan eldre mennesker vil, kan og bør integreres i sine familier, nærmiljøer og samfunn. Han trekker her på sosiologiske studier av eldres kår, og på sosialpolitiske argumenter, 
inklusive den britiske sosiologen Peter Townsends studier av eldre menneskers isolasjon, og den selvlærte forfatteren og byplan-teoretikeren Lewis Mumfords bredt anlagte samfunnsfilosofi. I sin konkrete diskusjon av hvordan leiligheter bør legges til rette for eldre har Boysen vist at disse også vil være fordelaktige for yngre mennesker og barnefamilier. I sin generelle diskusjon argumenterer han for at en generelt «høynet boligstandard» vil være den beste måten å bygge «eldreboliger» på. De konkrete kravene til boliger vil da også møte det han anser som en generell ambisjon om å unngå stigmatiserende særløsninger, og han avslutter artikkelen med følgende normative visjon:

Det vi nå er i ferd med å bli klar over, er at vår alder ikke er en [...] saklig begrunnet kategori. I et samfunn hvor vi har klart å løse miljøproblemene bedre enn i dag [og Boysen snakker om de sosiale miljøene], vil en nødtvungen segregasjon etter alder føles like unaturlig som de gamle rase- eller klasseskiller. (Boysen 1964, 25)

Det generelle alle som Boysen argumenterer for er altså det fellesskapet hvor et potensielt stigmatiserende skille mellom de «normale» og de «eldre» er utvisket, til fordel for en mer inkluderende normalitet. På et mer konkret nivå argumenterer han både for blandede boområder, den romslige «tre-generasjonsboligen», og en «høynet boligstandard» som tar hensyn til flere mulige funksjonshemninger, inklusive bevegelses- hørsels- og synshemninger ${ }^{3}$.

I forhold til Boysens forståelse av det generelle alle er det imidlertid en helt sentral spesifisering som må gjøres, og som vi må se til Boysens forhistorie for å forstå. Når Carsten Boysen begynte å jobbe på Byggforsk hadde han allerede en lang karriere som boligforsker og boligpolitisk aktivist bak seg. Den ser i korthet ut som følger: I 1932 stiftet han Socialistiske arkitekters forening, sammen med Erik Rolfsen, og i 1933 startet de arkitekt- og byplan-tidsskriftet PLAN. I dette tidsskriftet argumenterte Boysen og Rolfsen (og andre radikale arkitekter) for en strengt funksjonalistisk, rasjonalistisk og marxistisk arkitektur og byplanlegging. De Socialistiske arkitekters forening blir en del av Mot Dag-bevegelsen, og i 1936 reviderer Mot Dag-erne sin marxisme og melder seg kollektivt inn i Arbeiderpartiet.

I 1942 tar Boysen initiativ til den store boligundersøkelsen i Oslo (Guttu 2003, 54). Oslo Vel stiller seg bak undersøkelsen, hans radikale arkitektkollega Odd Brochmann leder den, og Boysen er med og skriver rapporten. Undersøkelsens viktigste funn er en dokumentasjon av at Oslos boligmasse preges av mange små leiligheter. Dette leder til en trangboddhet blant Oslos arbeiderklasse som er problematisk for mange. Det er spesielt kvinner og barn som lider under denne trangboddheten.

Etter krigen går de sentrale arkitektene i Socialistiske arkitekters forening fra opposisjon til posisjon. De blir strategiske arkitekter i Arbeiderpartiets gjenoppbygging av landet. Erik Rolfsen blir byplansjef i Oslo, Frode Rinnan tegner Lambertseter drabantby, og Carsten Boysen starter opp Norske Boligbyggelags Landsforbund. De blir derved med å forme den viktigste perioden i norsk boligbygging i moderne tid, nemlig arbeiderpartistatens storstilte sosiale boligbygging, i perioden fra 1945 til omtrent $1970^{4}$. Boligbyggingen i denne perioden var kjennetegnet av at man trengte mange boliger, større boliger, og at man trengte billige boliger.

Jon Guttu diskuterer hvordan denne boligbyggingen for de strategiske arkitektene i arbeiderpartistaten var formet av to sentrale faktorer. En rasjonalistisk arv fra 30-tallets funksjonalisme (og, bør vi legge til, dens marxisme), og en empirisk kjennskap til «trangboddheten» (Guttu 2003, 135). Fra sosialismen hadde de et fokus på sosial ulikhet, og et ønske om å minimere den, fra den rasjonelle eller praktiske siden av funksjonalismen hadde de en tro på at man kunne bygge funksjonelt, og fra den empiriske undersøkelsen i Oslo hadde de data som kunne informere dem. Et av de sentrale funnene fra denne undersøkelsen, skriver Guttu, var at toromsleiligheten var ubrukelig som familiebolig (Guttu 2003, 55). Det 
var sosialt vanskelig å bo så tett, spesielt, som sagt, for de som var mye hjemme; barna og mødrene. Familieboliger burde være på minst tre rom og kjøkken.

Dette sosialpolitiske bakteppet er helt sentralt for å forstå hvordan Boysen tenkte omkring «planlegging for alle», i forhold til eldre og uføre. Poenget er at når Boysen begynte å forske på boliger for eldre og uføre, så tenkte og arbeidet han innenfor et sosialpolitisk regime hvor det var bred enighet om å bygge gode og romslige boliger «for alle», og da med et sosialdemokratisk klasseperspektiv på «alle». Etablerte og mektige institusjoner som Husbanken og OBOS sørget for at man faktisk fikk bygget «boliger for alle». Når så Boysen vendte sin interesse mot de eldre og uføre, så var det for å inkludere disse gruppene $i$ det «alle» som allerede var etablert. Det «generelle alle» til Boysen, slik han utviklet det utover 60- og 70-tallet, skulle altså integrere mennesker på tvers av to viktige skiller: skillet mellom fattig og rik, og skillet mellom funksjonsfriske og uføre. Et sentralt virkemiddel for å realisere et «konkret alle» som favnet en stor andel av dette generelle alle var, i 1964, den generelt høynede boligkvaliteten. Dette var en bolig som var bygget med kunnskap om og sensitivitet til mange typer uføres behov, og som dermed kom alle til gode.

\section{Uførgruppa ved Byggforsk, 1970-tallet}

I 1967 etablerte NBI et laboratorium, hvor de kunne sette opp lettvegger og simulere aktiviteter. Disse ble så filmet ovenifra, og i denne labben begynte NBI å utføre sin egen planforskning, det vil si forskning på mulige planløsninger. I denne labben gjorde Boysen og hans kolleger studier av hvordan ulike rom i en bolig burde utformes for å kunne brukes av en person i rullestol (Boysen 1974).

Vi har intervjuet Tore Lange som begynte å jobbe på NBI i 1970, og som ble tilknyttet uføregruppa. På den tid fungerte Boysen som en kunnskapsrik senior for gruppa, forteller Lange. Han stilte alltid opp for yngre forskere, som generøs veileder og rådgiver, men han hadde ikke tatt sin egen publisering så veldig alvorlig. Den første oppgaven til Lange var å gå gjennom, systematisere og utgi Boysens notater.

De konkrete arbeidene til uføregruppa ble formet av en måte å tenke «universell utforming» på, men uten at de brukte dette begrepet. Et sentralt begrep for dem var det de kalte de «ukjente bruker». De tenkte seg dette som en abstrakt bruker som man ikke visste noen ting om. Kan hende var han/hun rullestolbruker, svaksynt, gammel, småbarnsmor eller far. Fokuset var - i tråd med Boysens arbeider fra 60-tallet - på det å unngå å designe «spesialboliger» for «funksjonshemmede», og det sentrale premisset de utviklet var at det å «planlegge for funksjonshemmede» var en god måte å «planlegge for alle» på (Boysen, Hansen, and Lange 1974; Boysen 1978; Boysen and Lange 1979). 


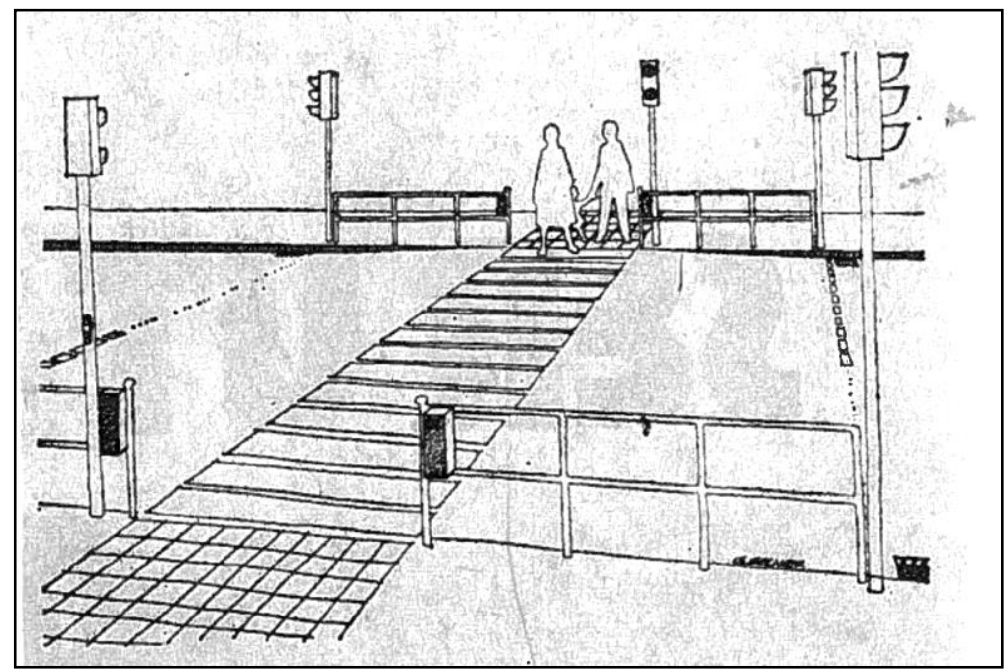

Figur 1: Tore Lange og Ragna Hansen argumenterer for hevet fotgjengerovergang i Arbeiderbladet, høsten 1970. Tegning av Gunnar Selnæs.

Konkret inkluderte uførgruppas arbeider studier av boligers planløsninger, men de inkluderte også planlegging av utearealer. De var blant de første i Norge til å argumentere for å heve fotgjengerfelt ved hjelp av fartsdumper (i Arbeiderbladet, 1970, se figur 1), slik at overgangen fortau-fotgjengerfelt ble plan for rullestolbrukere, og med lydsignaler for blinde. Gruppen jobbet også med hvordan man burde legge boliger i bratt terreng på en måte som sikret tilgjengelighet «for alle» (Bjørneboe 1977).

Alle forskerne ved uførgruppa ved NBI tilhørte den politiske venstresiden i norsk politikk. De «moderate» var SV-ere. I samtaler med flere av gruppas representanter går følgende klart fram: «Uførgruppa» skrev innenfor et boligpolitisk paradigme hvor en sterk markedsregulering var en selvfølge. De boligpolitiske seirene som Boysen og hans kolleger hadde kjempet fram etter krigen, i kampen mot «trangboddheten», var nettopp det; seire. Noe de i stor grad hadde vunnet. Boligsamvirkene og Husbankens låneordninger var ikke perfekte, men de var virksomme, politisk legitime og veletablerte institusjoner som sørget for at boliger fikk en rimelig størrelse, et rimelig godt utemiljø, og rimelig gode planløsninger. På 1970tallet kunne man gjerne kritisere disse institusjonene for deres mangler, også på venstresiden, men man kunne ta deres eksistens for gitt (se for eksempel "Ammerudrapporten" (Sæterdal og Hansen 1969)).

I det store og hele viderefører derfor uførgruppa de samme forståelsene av «alle» som Boysen formulerte i 1964, og som vi kan kalle den sosialdemokratiske versjonen av universell utforming; det generelle alle inkluderer de befolkningsgrupper som splittes av skillene mellom fattige og rike og mellom «normale» og «uføre». Det konkrete alle fanges inn ved å bygge for funksjonshemmede og eldre på en måte som derved også kommer andre grupper til gode, blant annet ved at generell «brukbarhet» og romslighet var en del av løsningene. Det «generelle alle» som lå bak uførgruppas konkrete arbeider var altså av en slik art at man burde bygge rullestolvennlige boliger enten rullestolbrukeren var fattig eller rik.

\section{Livslopsboligen, 1981, som et «konkret alle»}

Innsnevringen fra et generelt alle til et konkret alle kan skje på mange måter. Avgreningene kan være politisk bestemte, gitt av at noen interessegrupper er flinkere til å fremme sin sak enn andre, eller gitt av pragmatiske og relativt tilfeldige hendelsesforløp. I det følgende skal vi se hvordan Boysens sosialdemokratiske versjonen av «planlegging for alle» i løpet av 1980-tallet snevres inn til et konkret alle som i stor grad gikk ut på å bygge boliger som hadde som målsetning om å sikre tilgjengelighet for bevegelseshemmede. Vi vil se hvordan en 
ganske tilfeldig kombinasjon av kunnskapsproduksjon og interessekamp kan lede til en slik innsnevring.

I det vi har av skriftlig materiale fra Norges Byggforskningsinstitutt ser det ut til å foregå en bestemt innsnevring av uførgruppas konkrete fokus utover 1970-tallet. NBIs uføreforskning får et noe ensidig fokus på rullestolbrukeren og den bevegelseshemmede (Gulbrandsen 1975, 233:1). Det er ikke fordi de har villet det, ifølge Gulbrandsen, men fordi NBI «foreløpig» kun har forsket på bevegelseshemninger. Uførgruppa utførte riktignok forskning på andre typer uførhet, blant annet det de kalte «usynlig» funksjonshemming, som astma og allergier, men Gulbrandsen har nok ikke helt feil i sin beskrivelse: Det er mye fokus på bevegelseshemninger i NBIs forskning, og på hvordan disse kan kompenseres.

Dette er en pragmatisk innsnevring som får en bestemt oppfølging. I 1981 lanserer FN Handikapåret, og som en del av denne satsingen lanserte Norges handikapforbund «livsløpsboligen» (Seierstad, Jacobsen, and Bringa 1981). De bygger første etasje av en «livsløpsbolig» på bildekket til en innleid danskeferge og drar på «messecruise» kysten rundt. Handikapforbundet trekker på mye av NBIs forskning når de utformer livsløpsboligen, blant annet på hvordan man bør bygge i bratt terreng (Bjørneboe 1977), og på byggforskblad A.330.211, «Tilpasning til bevegelseshemmede generelt» (Boysen, Lange, and Svennar 1979). I 1985 omarbeides dette byggforskbladet i et samarbeid mellom NBI, Husbanken og Handikapforbundet (Christophersen 1990, 70: III), og utgis under navnet Livsløpsboliger (Lange and Ringnes 1985).

Den første publikasjonen som definerer Livsløpsboligen er interessant ved at den både tydelig formulerer et generelt alle og et konkret alle. Det generelle alle ser vi i følgene formulering:

Norges handikapforbund ønsker ikke å få forskrifter som sikrer generelt anvendelige boliger primært med hensyn til «de funksjonshemmede». I dette uttrykket ligger ofte en oppfatning av funksjonshemmede som en statisk gruppe. Vi vet at funksjonshemminger oppstår innenfor den boligmasse vi har og innenfor den befolkning vi har. Derfor ønsker vi trygghet for hele befolkningen gjennom generelt anvendelig boligmasse. (Seierstad, Jacobsen, and Bringa 1981, 4)

Her ser vi et generelt alle som i stor grad ligner på det generelle alle som Boysen formulerer $\mathrm{i}$ 1964: Det inkluderer potensielt alle de funksjonshemminger som «oppstår innenfor den boligmasse vi har og innenfor den befolkning vi har», det vil si også alle de funksjonshemminger som kjennetegner alderdommen: Svaksynthet/blindhet, tunghørthet/ døvhet, bevegelsesvansker, glemsomhet etc. Når man så blar om til de sidene som spesifiserer et konkret alle, skjer det imidlertid en meget klar innsnevring av «alle»: Livsløpsboligen spesifiserer kun arealplanmessige grep som sikrer tilgjengelighet for bevegelseshemmede, først og fremst rullestolbrukere (Seierstad, Jacobsen, and Bringa 1981).

Vi ser den samme innsnevringen i byggforskbladet A 330.211. I 1979 het bladet Tilpasning til bevegelseshemmede generelt (Boysen, Lange, and Svennar 1979). I 1985 utgis en revidert versjon og det heter nå A 330.211 Livsløpsboligen. Omarbeidelsen er minimal. Det er fortsatt den bevegelseshemmede som står i sentrum. Hovedendringen består i at det bladet som i 1979 kun ga seg ut for å handle om bevegelseshemmede nå i sin innledning hevder å dekke interessene til «eldre» og «funksjonshemmede» generelt (Lange and Ringnes 1985, 1), mens det $\mathrm{i}$ sitt innhold fortsatt har et fokus på hvordan man kan unngå å skape et bevegelseshemmende miljø. Dette er ikke helt urimelig - svært mange eldre blir bevegelseshemmende, men det innebærer en innsnevring av hvilke hensyn som skal tas. Innsnevringen fra et generelt alle som skulle nå «alle» til et konkret alle som i stor grad formulerte tilpasninger til bevegelseshemmede kan $i$ noen grad knyttes til at de bevegelseshemmedes interesseorganisasjon, Handikapforbundet, var sentrale i å fremme 
livsløpsboligen. Men det kan i noen grad også knyttes til det at det ikke fantes en praktisk, implementerbar kunnskap om hvordan man kunne bygge for å unngå disse, blant annet på grunn av kunnskapsgrunnlaget og forskningsfokuset til Byggforsk.

Livsløpsboligen har imidlertid et interessant etterspill, hvor det konkrete alle igjen utvides, til å større grad å bli et bredt sosialpolitisk prosjekt, som skulle møte behovene til et bredt definert «alle».

\section{Minstestandarden, 1992}

Etter at Willoch-regjeringen av 1981 liberaliserte boligmarkedet mistet Husbanken mye av sin innflytelse på boligpolitikken (Reiersen, Thue, and Jensen 1996). Men liberaliseringen skaper en enorm boligboble, som sprekker på slutten av 1980-tallet. I 1992 er det fortsatt bankkrise og kollaps i boligmarkedet, og under Brundtlands tredje regjering får Husbanken gjennomslag for en revitalisering av den sosiale boligpolitikken, og er dessuten nesten eneste bank som finansierer de få boligene som bygges. ${ }^{5}$ I 1992 innfører Husbanken et krav om at en bolig som skal ha basislån må innfri kravene til det de kaller en «minstestandard». Hvis den også oppfyller livsløpsstandarden kan man også få tilleggslån (Reiersen, Thue, and Jensen 1996, 417).

Minstestandarden var ikke laget for å møte spesifikt «funksjonshemmedes» behov. Den definerte hva en bolig skal inneholde av rom/funksjoner. Videre stilte den krav til ulike funksjoner i boliger med ulik størrelse og anga en norm for størrelsen på for eksempel kjøkken for boliger med 2, 3 eller 4 rom. Standarden med sine normer var laget for å gi leilighetene en generelt høynet boligstandard. En konsekvens av de normsatte bruksfunksjonene var at en fikk en minimumsstørrelse for ulike boligtyper. I 1994-utgaven skulle en 2 roms leilighet ha minimum 55 kvadratmeter, en 3 roms 65 kvadratmeter, osv. ${ }^{6}$, gode lysforhold, et minimum av «privat uteplass», med mer.

Det interessante med minstestandarden er at selv om den ikke spesifikt var laget for å møte funksjonshemmedes behov, så ga den et bedre grunnlag for livsløpsboligen på en viktig måte: Den tilførte leiligheter de fleste av de kvalitetene som Boysen i 1964 mente at en «høynet boligstandard» burde ha for å være egnet til eldre og uføre.

Poenget er ikke at de som laget minstestandarden leste Boysens artikkel fra 1964. Det gjorde de neppe. Poenget er at en «generelt høynet boligstandard» (Boysen 1964), det vil si en bredde av informerte funksjonskrav og normeringer, ikke behøvde å bli formulert som en «tilpasning til funksjonshemmede», fordi kombinasjonen av minstestandarden pluss livsløpsstandarden både ville komme «vanlige» og «funksjonshemmede» beboere til gode.

Det spesielle med Husbankens minstestandard + livsløpsstandard ligger heller ikke $i$ at dette var et veldig vidløftig forsøk på å formulere et «generelt alle». Det spesielle ligger i at det var et ambisiøst forsøk på å bygge et bredt «konkret alle». Når Husbanken la minstesstandarden til livsløpsstandarden så fikk man en implementasjon av den sosialdemokratiske versjonen av universell utforming innen boligfeltet. Stort nærmere en konkretisering av de prinsippene Boysen teoretiserte i 1964 kommer vi ikke.

Og nærmere kom vi ikke, for det politiske Norge var forandret. Arbeiderpartistaten var avviklet, og utover 1990-tallet blir det klart at Husbanken ikke har den politiske støtten de hadde trengt for å gi «minstestandarden + livsløpsboligen» realpolitisk tyngde. Det ble ikke bygget så mange boliger med denne formen for husbankstøtte, og i 2005 setter Bondevik IIregjeringen den siste spikeren i kisten til arbeiderpartistatens sosiale boligbygging, og avvikler minstestandarden.

Med den avviklingen var det bare Byggteknisk forskrift av 1997 som satte krav til hva en «bolig» skulle være, funksjonelt sett, og den forskriften anga ikke andre bindende krav enn at ingen rom må være mindre enn 15 kubikkmeter store (noe som gir en gulvflate på $6.25 \mathrm{~m}^{2}$ ved takhøyde på 2.40). Det var fritt fram for å bygge så små boliger man kunne, så lenge det 
var etterspørsel nok, og 2-romsboliger ned mot $25 \mathrm{~m}^{2}$ begynner å se dagens lys (Nørve, Denizou, og Knudsen 2006). Markedsforhold og avvikling av husbankens krav til minstestandard underminerte den «generelt høynede boligstandarden».

«Universell utforming» som et reguleringsspolitisk «generelt alle»

De siste 15 årene kan utviklingen innenfor feltet planlegging for alle karakteriseres med følgende to punkter, som begge er ganske spektakulære:

- Etablering av begrepet «universell utforming». Med dette begrepet fikk vi det mest omfattende generelle alle som noen gang er formulert. Ikke bare inkluderer det «alle» mennesker, men det er anvendelig på «alle» teknologiske områder, fra boksåpnere til busser.

- Innen feltet plan, bygg og bolig: Formuleringen og iverksettingen av Byggteknisk forskrift av 2010 (TEK 10). Som formulering av et konkret alle er den mindre ambisiøs enn for eksempel livsløpsboligen eller minstestandarden, men den er likevel en ganske spektakulær nyvinning ved at de normeringene den gjør er juridisk bindende for alt som bygges. Med TEK 10 skjer det derved en rettsliggjøring (eller en "reguleringspolitisk vending") av ideen om å planlegge for alle.

Det Tøssebro beskriver som en reguleringspolitisk vending består $\mathrm{i}$ at virkemiddelet for politikken blir lover og forskrifter. Men som vi antydes innledningsvis, så er vendingen de siste 15 årene mye mer enn reguleringspolitisk. Endringen må forstås i lys av at det fantes en sosialdemokratisk planlegging for alle før universell utforming så dagens lys. Det nye kommer ikke i tillegg til denne planleggingen, slik Tøssebro beskriver universell utforming som et tillegg til en etablert velferdspolitikk. Det ville jo vært fint om den kun kom i tillegg til noe allerede etablert, for da hadde man et entydig framskritt å forholde seg til: Før universell utforming fikk man rullestol av velferdsstaten, etter universell utforming, kan man også komme seg rundt med den.

Innen boligfeltet kommer imidlertid den nye versjonen av «planlegging for alle» $\mathrm{i}$ stedet for den gamle versjonen, og da blir bildet mer komplisert. Vendingen, helt kort, synes å bestå $\mathrm{i}$ at det å jobbe for en bred allianse mellom «vanlige» og «funksjonshemmede» mennesker - hvor det å bygge for «funksjonshemmede» også kommer «vanlige» mennesker til gode, erstattes av en interessepolitikk vending, der tydeliggjøring av gruppene og deres likestillingskrav kommer foran den radikale normaliseringen som ligger $i$ å viske ut skillet mellom «vanlige» og «funksjonshemmede».

Vendingen vi i det følgende skriver om skjer ikke når Bringa og Rådet for funksjonshemming utformer begrepet universell utforming, i 1997-1998. Vendingen skjer utover 2000-tallet, og vi skal i det følgende se nærmere på hvordan den skjer. Først skal vi se litt nærmere på hva Olav Rand Bringa og Rådet for funksjonshemming gjorde når de i 19971998 for første gang formulerte begrepet «universell utforming» på norsk.

\section{Begrepet «universell utforming» som et generelt alle}

Begrepet «universell utforming» slår veldig godt an innenfor funksjonshemmingsfeltet, bedre enn noen formulering fra 1970-tallets byggforskning. Det er flere grunner til dette, og uten å gi noe uttømmende analyse, så var nok følgende faktorer viktig: «Universell utforming» hadde, som sagt, en bred appell, ved at det kunne brukes om all mulig design. Det var ikke bare en språklig nyvinning, men det var også et egennavn. Derved fungerer begrepet som et selvstendig symbol. Vi ser betydningen av dette allerede i det arbeidet Bringa og Rådet for funksjonshemning gjorde på midten av 1990-tallet. I 1995 utgir de en veiviser som heter Veiviser: tilrettelegging av noermiljø for funksjonshemmede (Bringa 1995). I 1997 lanserer de 
som sagt begrepet «universell utforming»(Aslaksen mfl. 1997). I 1998 oppdaterer de så veiviseren. Den nye versjonen er nesten identisk med den gamle, og innholdsmessig består den viktigste endringen $\mathrm{i}$ at referansene til TEK 87 byttes ut med referanser til TEK 97 (Bringa 1998). Men den viktigste endringen lå i tittelen. Den andre utgaven heter Veiviser til universell utforming. I den første tittelen ga konteksten «for funksjonshemmede» mening til «tilrettelegging»; tilrettelegging av noermiljø for funksjonshemmede. Men derved lukket man ikke det semantiske rommet for den potensielle stigmatiseringen som det å tilrettelegge «for funksjonshemmede» muliggjør. Man planla ikke for «alle», men for «funksjonshemmede».

I andre versjonen av dokumentet begynner Bringa og Rådet for funksjonshemming å få et språk som løsriver deg fra segregeringen og stigmatiseringens logikk, og de kan for alvor begynne å snakke om en «planlegging for alle» uten å gå veien om dikotomien mellom «normale» versus «funksjonshemmede».

Språklig sett, som en formulering av et «generelt alle», nådde altså «universell utforming» langt. Det var ikke bare et middel på vei mot de etter hvert klassiske målsetningene om normalisering, inkludering og anti-stigmatisering, innen funksjonshemmingspolitikken. «Universell utforming» var, språklig sett, et oppnådd mål. Det var en måte å snakke om «planlegging for alle» på som hevet seg over stigmatiseringens språklige logikk.

Når Manneråkutvalget i 2001 adopterte «universell utforming» som en hovedsatsing for fremtidens funksjonshemmingspolitikk, så var det nettopp med referanse til at begrepet muliggjorde en radikal form for «inkludering» av de som før var ekskludert fra det «normale». Universell utforming er et gode fordi «alles tilhørighet er en selvfølge, og en bør slutte å benytte ord som impliserer at dette ikke er tilfelle» (NOU 2001, 32).

I tillegg til denne inkluderende egenskapen ved begrepet «universell utforming» var Bringa nøye med å skrive på en måte som ikke skapte politiske eller ideologiske utsider. Altså, de første dokumentene om universell utforming hadde ingen tydelig politisk slagside, slik at det appellerte mer til en politisk ideologi enn til en annen. Dokumentene appellerte til alle politiske retninger, og Bringa kunne snart notere seg at de fleste politiske partier støttet prinsippet om universell utforming, fra SV til Høyre (intervju).

Det som altså skjer, på begynnelsen av 2000-tallet, er at begrepet på en viktig måte avpolitiseres. Det vil si; det er nesten ingen som er uenig i at universell utforming er en god ting.

\section{Generaliseringens grenser}

I kraft av å være en meget vellykket formulering av et generelt alle, begynner begrepet «universell utforming» utover 2000-tallet sin reise gjennom forvaltning og organisasjonsliv, for å operasjonaliseres som ulike former for konkrete alle. Hva skjer da? Vel, vi kan være ganske sikre på én ting: Da vil innsider og utsider igjen måtte oppstå. Man kan ikke tilrettelegge absolutt alt for absolutt alle. Da vil også politikken kunne gjenoppstå, i den forstand at ikke alle politiske grupperinger liker alle konkretiseringer like godt. Men derved er det ikke sikkert at det generelle prinsippets avpolitisering blir en entydig fordel, for da risikerer man at politikken som bør følge konkretiseringene erstattes av en rent faglig iverksetting. Derved avpolitiseres den viktigste delen av den politiske prosessen; feltet der visjoner skal bli handling

Det er faktisk utydelig hva slags politikk som vil følge av ulike konkretiseringer av «universell utforming». Det er derfor nytting å belyse hva den regulerings- eller interessepolitiske vendingen består i når universell utforming konkretiseres. Vi skal gjøre det ved å analysere tre caser: 1) informasjonskampanjen «ingen hindring», 2) et skifte i fokuset til Handikapforbundets informasjonsbrosjyrer om «universell utforming», og 3) implementeringen av universell utforming i den tekniske forskriften TEK 10. 


\section{«Ingen hindring»}

I 2005 starter Husbanken, Kommunal- og regionaldepartementet og Statens bygningstekniske etat kampanjen Ingen hindring. En annonse og en informasjonsbrosjyre forsøker å omsette det generelle alle i universell utforming til radikale konkretiseringer. I annonsen (som sto på trykk i Adressevisen ${ }^{7}$ ) er det bilder av 8 mennesker og en dør, og tittelen er «kommer alle inn denne døra?» (se figur 2, neste side). En mann er veldig høy, en kvinne er gravid, og «Geir (56)» er noen ganger rullestolbruker, men er i annonsen avbildet stående. Alle kommer gjennom døra, for den er universelt utformet. Det radikale $\mathrm{i}$ annonsen består $\mathrm{i}$ at ingen av de åtte som er avbildet sitter i rullestol eller på andre måter er stereotypisk «funksjonshemmet». Med slagordet «Bra for alle - nødvendig for noen»er budskapet at det å være «funksjonshemmet» bare er en annen måte å være «vanlig» på.

I brosjyren «Vi har en plan - om å skape et samfunn for alle», utgitt av Deltasenteret (i samarbeid med flere), er bilde- og ordbruk den samme: Ingen stereotypisk «funksjonshemmede» er avbildet. Man ser en barnevogn, men ingen rullestol (Deltasenteret 2006).

Norges handikapforbund liker imidlertid ikke dette forsøket på konkretisering av de generelle målsetningene bak «universell utforming», og i 2006 innkaller de til møte. Bakgrunnen for møtet er, skriver de, at «vi mener at funksjonshemmede i økende grad usynliggjøres; rullestolen er erstattet av barnevogn, blinde personer av den spreke pensjonisten med briller» ${ }^{8}$. De er opptatt av å formidle at universell utforming bør være en strategi for å inkludere de funksjonshemmede i samfunnet. Og det er tydelig at for Norges handikapforbund er det ikke noen målsetning å komme dit at «de funksjonshemmede» bør integreres så godt at man kan slutte å snakke om dem som en gruppe, slik Deltasenteret og de andre deltagerne i kampanjen forsøkte seg på.

Handikapforbundets initiativ leder til en serie møter, og det direkte resultatet er at Miljødepartementet utgir en «begrepsavklaring» (Miljøverndepartementet 2007). Teksten er kort og generell, og mesteparten av det som skrives er kjent fra tidligere publiseringer om universell utforming. En enkelt setning kan vel sies å gi Handikapforbundet det de ber om: «Et hovedsiktemål med universell utforming er å oppnå likestilling og deltagelse for personer med nedsatt funksjonsevne ...»(Miljøverndepartementet 2007, 8). Hovedsiktemålet med universell utforming er altså ikke bedre bygg og tilgjengelighet for «alle», inklusive barnevognbrukere, men bedre og mer tilgjengelige bygg for å bedre likestilling og deltakelse for personer med nedsatt funksjonsevne, så som rullestolbrukere.

Denne ene publikasjonen fra Miljødepartementet er neppe avgjørende for så veldig mye, men de radikale informasjonskampanjene om universell utforming avsluttes, og dette representerer en viktig dreining $\mathrm{i}$ det politiske arbeidet med å konkretisere prinsippet universell utforming som praktisk politikk. Informasjonskampanjene som Handikapforbundet reagerte mot prøvde å gjøre universell utforming relevant for alle. Kampanjene prøvde å bygge et skjebnefellesskap mellom «vanlige» småbarnsfamilier, «funksjonshemmede» rullestolbrukere og svaksynte på en måte som plasserte de tidligere «funksjonshemmede» inn i den store normaliteten, «oss alle».

Når man så leser de informasjonsbrosjyrene som Handikapforbundet har utgitt om universell utforming, i perioden fra 1998 til 2010, så blir det tydelig at forbundet har foretatt et strategisk skifte i perioden rundt 2006-2007, bort fra en forståelse av universell utforming som et middel for normalisering, og mot en mer interessepolitisk vending der gruppen tydeliggjøres som gruppe. Neste seksjon presenterer denne dreiningen. 


\section{KOMMER ALLE INN DENNE DØRA?}
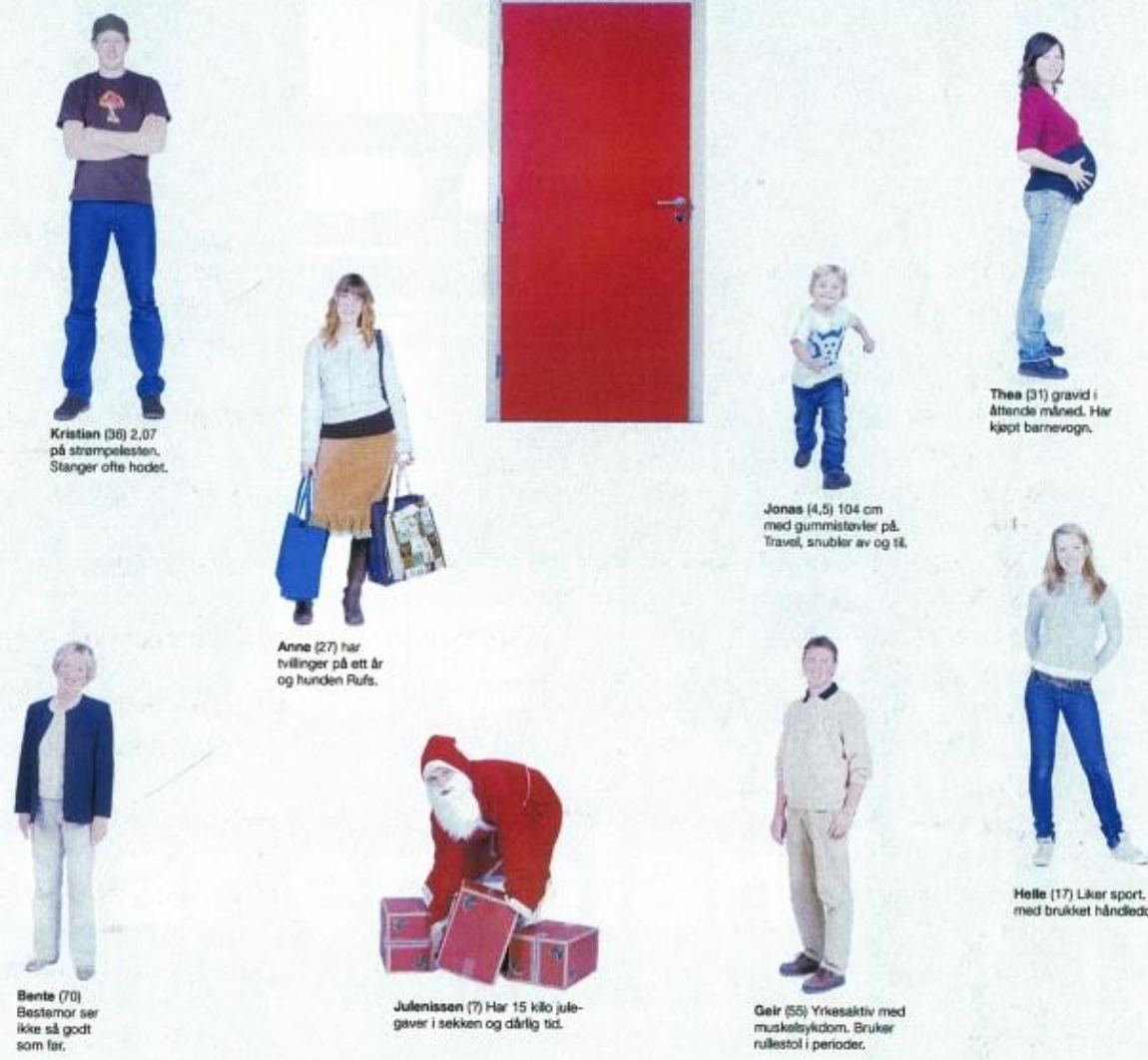

Helle (11) Lker sport, Nat
med brieket handodod.

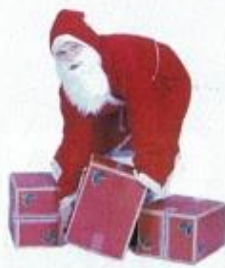

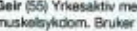

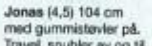

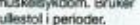

\section{Bra for alle - nødvendig for noen}

I lopet av livet opplever vi at funksjons- Universell utforming gir omgivelser alle evnen vár varierer. Muligheten til à delta kan bruke. Universell utforming gir smarte isamfunnsivet er avhengig av hvordan losninger du kan leve lenge med.

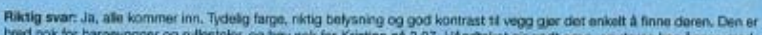

通窥 Husbanken

时
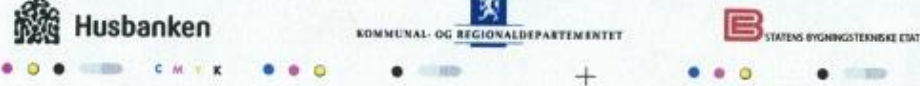

Figur 2: Husbanken, Kommunal- og regionaldepartementet og Byggeteknisk Etats annonse i kampanjen «Ingen Hindring».(Trykket i Adresseavisen i 2006, nøyaktig dato ikke kjent) 


\section{Handikapforbundets brosjyrer}

Handikapforbundets første fire brosjyrer om universell utforming utgis i perioden 1998 til 2001. Disse er klart preget av Bringas første publiseringer om «universell utforming» (Aslaksen mfl. 1997; Bringa 1998). Det vil si, de har et fokus på allerede vellykkede boligprosjekter, og på kommunal samfunnsplanlegging, etter Plan- og bygningsloven (Bergh and Henriksen 1998; Haug 2001; Haug and Aslaksen 1998; Heggem and Dobloug 2000; Myrdal 2005). I disse publiseringene ser vi flere eksempler på nye «livsløpsboliger» bygget med husbankfinansiering, som derved møter både minstestandarden og livsløpsstandarden. Selv om målet er inkludering av funksjonshemmede, så er middelet bredt: Handikapforbundet skriver om boligbygging på en måte som møter mange behov, inklusive de til «mennesker med funksjonshemming», og i bildematerialet er lekende barn i trygge bomiljøer og barnevogner på vei inn eller ut av busser like fremtredende som rullestolbrukere. Et bilde viser et uteareal utenfor et borettslag, og vi skjønner at det er godt tilrettelagt for alle, uten at det er mulig å se at det er spesielt «tilrettelagt» for «bevegelseshemmede» (Haug 2001, 5), et annet av et torg med mange mennesker, hvor vi kun skimter et par krykker blant et mangfold av folk (Haug 2001, 29). Bildene viser også funksjonshemmede mennesker som er grunnleggende avhengige av andre, og gjennom den avhengigheten inkludert på en god måte, for eksempel i from av et rullestolbrukende barn som er en del av en kjernefamilie (Haug 2001, 6). I disse første brosjyrene om universell utforming beveger altså Norges Handikapforbund seg ganske langt i samme retning som Boysens versjon av «planlegging for alle» og som i 2005-kampanjen til Deltasenteret med flere; mot en utvisking av skillet mellom de «vanlige» og de «funksjonshemmede». Universell utforming framstår som en strategi for å oppnå større grad av assimilering; den "funksjonshemmede" smelter i større grad inn i en bred normalitet.

De informasjonsbrosjyrene som Handikapforbundet utgir etter ca. 2006 representerer et tydelig skifte. Borte er referansene til lekende barn og til allerede vellykkede eksempler på «livsløpsboliger». Et viktig skifte i orienteringen er en større vekt på deltagelse i kommunale planprosesser, heller enn kun et fokus på det ferdige resultatet (Hanssen 2010; Henriksen 2007; Henriksen and Huvenes 2008). Gjennom medvirkning og deltagelse skal funksjonshemmede hevde sine interesser og delta $\mathrm{i}$ politikkens planlegging og implementering. Handikapforbundet tegner ikke lenger en visjon av et samfunn hvor skillet mellom «funksjonshemmet» og «vanlig» er visket ut, slik de gjorde i sine første fire brosjyrer om universell utforming, før 2006. De presenterer en interessegruppes legitime kamp for en plass ved forhandlingsbordet. De funksjonshemmede er nå en tydelig stemme, som er til stede som en gruppe, ikke «inkludert» $\mathrm{i}$ den forstand at de er blitt «like», som en «naturlig» eller usynlig del av et stort fellesskap. Men inkludert $\mathrm{i}$ den forstand at de lyttes til i en interessekamp mellom ulike grupper.

Dette fokuset forsterkes av bildematerialet, som i mye større grad viser bilder av funksjonshemmede, ikke lenger av barn og barnevognbrukere. Vi ser rullestolbrukerne som er frigjorte ved hjelp av rullestolen. Og med den ruller de seg til forhandlingsbordet hvor de som sterke, voksne, aktive og politiske individer er like taleføre som alle andre (Henriksen and Huvenes 2008, 29). Poenget til brosjyrene er ikke å vise at en politiker som Guro Fjellanger både kunne være (en god) miljøvernminister og rullestolbruker. Poenget er å vise at den politikken bevegelseshemmede utfører, den gjør de på vegne av seg selv, som bevegelseshemmede.

\section{Likeverdig men forskjellig?}

For ulike grupper funksjonshemmede kan retten til å være likeverdig, men forskjellig, være 
like viktig som retten til å være lik. Spenningen mellom likhet og likeverd definerer mange debatter og politiske kamper innen funksjonshemmingsfeltet. Den er kanskje mest kjent i kampen som mange døve har ført i forhold til retten til ikke å få høreapparater operert inn i ørene. Implantatet kan gi et døvt menneske hørsel, dårlig hørsel, men mer enn ingen hørsel. I kampen mot disse implantatene argumenterer tegnspråk-brukere for at de - tegnspråkerne må respekteres som et eget språkfellesskap, altså som en kulturell minoritet, likeverdig med andre minoriteter (Breivik 2006). Når døve argumenterer mot at de, eller deres barn, skal «normaliseres» ved hjelp av et cochlea-implantat i øret, så er argumentet at det er bedre å være et kompetent medlem av tegnspråkets kulturelle fellesskap, enn å være et dårlig medlem av det hørendes fellesskap. Da må tegnspråkets utøvere betraktes som likeverdig, men forskjellig fra lydspråkenes utøvere.

Det er noe likt i Handikapforbundets kamp for synlig anerkjennelse som kapable og autonome bevegelseshemmede og de døves kamp for å få være kapable og synlige tegnspråkere. Ingen av dem ser noen fordel i bare å forsvinne inn i en stor normalitet. Det er imidlertid en viktig faktor som skiller dem: Handikapforbundet har ikke adoptert noen ideologisk forskjellsetikk, av typen «likeverdig og forskjellig». Den ideologiske målsetningen til Handikapforbundet, etter 2006-2007, er fortsatt «full deltakelse» (Henriksen and Huvenes 2008, 6), og tekniske løsninger som kan «brukes av alle» (ibid, 7). På det generelle planet erstatter ikke brosjyrene etter 2006 de tidligere brosjyrene om universell utforming. De supplerer dem. Det at «universell utforming» er et middel for funksjonshemmede (ikke for barnevognbrukere), og at bevegelseshemmede oppfordres til å drive politikk på vegne av gruppen bevegelseshemmede er derved en pragmatisk, interessepolitisk strategi. Det er en form for konkretisering av universell utforming hvor man erkjenner at det generelle målet om «planlegging for alle» aldri vil nås som en ferdig utformet utopi (som er ferdig «planlagt for alle»). Konkret må det ideelle målet «universell utforming» må formuleres som en politisk kamp, som må vinnes igjen og igjen.

\section{Fra universell utforming til TEK 10}

I løpet av 2000-tallet ble Plan- og bygningsloven revidert, og det var igjennom dette arbeidet at prinsippet om universell utforming fikk sin første konkretisering innen areal- og bygningspolitikken. I prosessen med ny Plan- og bygningslov har både et Planlovutvalg og et Bygningslovutvalg vært i arbeid. Bygningslovutvalget ble nedsatt i 2002 og leverte to innstillinger (NOU 2003; NOU 2005b). Utvalget fant at kravene tilgjengelighet og brukbarhet ikke var godt nok ivaretatt i lovgivningen og sluttet seg til prinsippet om universell utforming. Universell utforming var godt egnet til bruk på overordnet nivå, men var for lite spesifikt og funksjonsrettet til å kunne angi rettslig bindende rammer for løsninger på konkret og detaljert nivå. Begrepet trengte stor grad av konkretisering (NOU 2005b, 408-409).

Ny Plan og bygningslov ble vedtatt i 2008, og i tråd med bygningslovutvalgets anbefalinger ble universell utforming tatt inn i lovens fellesbestemmelser som mål for det enkelte byggetiltak (kap. §1-1, ledd 5), mens de rettslig bindende rammene for lovens målsetninger ble formulert i den nye versjonen av Byggteknisk forskrift av 2010 (TEK 10). Spørsmålet er så: Hva slags konkretisering av universell utforming er det som formuleres i TEK 10? Kan vi si at med TEK 10 har universell utforming fătt sitt endelige gjennombrudd? Nei, vi kan ikke si det. Ikke fordi det ikke har vært visse gjennombrudd, men fordi saken er mangesidig. Vi trenger både å sammenligne TEK 10 med sin forløper, TEK 97, og med andre konkretiseringer av «planlegging for alle», for å se hva som er vunnet med TEK 10, eventuelt hva som er tapt.

Det byggtekniske miljøet hadde lenge argumentert for en hierarkisk oppbygging av forskriften der funksjonskrav angir hva som var ønsket av sluttresultatet (Cronberg 1977) ${ }^{9}$. De ulike tekniske løsningene kunne så endres over tid, for eksempel gjennom utvikling i 
materialteknologi, og velges av utbygger. Hvilke løsninger som tilfredsstilte funksjonskravene kunne så framgå av veilederen. Funksjonskravene skulle være å forstå som minstekrav. Denne oppbyggingen av krav ble innført fra og med 1997, i TEK 97 og dens tilhørende veileder, og prinsippet er den samme i dagens lovgivning.

Ulempen med denne oppbygging av forskrift og veiledning, slik den ble implementert i TEK 97, var at veiledningen ikke var juridisk bindende, og forskriften sa heller ikke noe om hvordan veiledningen var å forstå. Den ble derfor avveket (se Nørve 2009, 102). I tillegg var kravene i TEK 97 utydelige og ga rom for store tolkninger. Håndhevelsen var heller ikke spesielt god. Mange argumenterte derfor for at de konkete kravene mht. dørbredder, arealkrav til baderom og lignende skulle tas direkte inn i forskriften. Dette er til en viss grad gjort i TEK 10. I tillegg er kravene tydeliggjort og hvordan funksjonskravene skal forstås og verifiseres, er nedfelt $\mathrm{i}$ forskriften ${ }^{10}$. TEK 10 er derfor styrket på flere måter i forhold til TEK 97.

Det som har skjedd med TEK 10 er at dette argumentet har fått gjennomslag: En rekke konkrete krav er flyttet fra veiledningen til forskriften, og en rekke nye krav har dessuten blitt formulert, og da i forskriften ikke (bare) i veiledningen. For eksempel er kravet om dørbredde på minst $90 \mathrm{~cm}$ (noen steder $80 \mathrm{~cm}$ ) flyttet fra veilederen til forskriften, mens de uspesifiserte kravene om tilretteleggelse for «orienteringshemmede» (inklusive svaksynte) er konkretisert på mange måter, for eksempel i krav om målbare kontrastfarger på diverse detaljer (typisk «luminanskontrast på $0,8 »)$.

Videre innfører TEK 10 et viktig skille, nemlig mellom «universelt utformede bygninger» og «tilgjengelige boenheter» (TEK 10, Kommunal- og regionaldepartementet $2010 \S 12-1$ og $\S 12-2$ ). For bygninger med krav til universell utforming (byggverk for publikum og arbeidsbygninger) stilles det en rekke krav knyttet til rom, atkomst og kommunikasjonsveier. Dette handler om bredder og stigningsforhold i atkomsten og korridorer, samt en rekke krav til belysing, synlig luminanskontrast, merking, taktile felt osv. Forskriften stiller også krav om romakustikk og lyd- og taleoverføringsutstyr.

Vi ser altså at for arbeids- og publikumsbygg definerer TEK 10 et bredt konkret alle, en krets som innbefatter synshemmede, hørselshemmede og rullestolbrukere.

Boliger har ikke krav om «universell utforming» etter den definisjonen av «universell utforming» som forskriften selv lager. De skal primært være tilgjengelige, det vil si ha trinnfrie utearealer og kommunikasjonsveier, minimumsbredde for korridorer og svalganger og passasjer i den enkelte bolig. Den tilgjengelige boenhet skal ha størrelse og planløsning som muliggjør bevegelse med rullestol. Den formulerer også krav til som god belysning av arealer, visuelt og taktilt oppmerksomhetsfelt foran hovedinngang. Men kravene til «tilgjengelig boenhet» har færre krav knyttet til syns- og orienteringshemmede og noe svakere krav knyttet til tilgjengelighet med rullestol enn det en «universelt utformet bygning» har.

Det gjennomgående mønsteret i disse spesifiseringene er, for det første, at de styrker de konkrete kravene om hva «tilgjengelighet» skal bety (i forhold til TEK 97). For det andre skjer denne styrkede konkretiseringen ved at forskriften i hovedsak lar rullestolbruk være definerende ${ }^{11}$.

Som en kort oppsummering av hvordan det generelle alle som ble formulert gjennom prinsippet «universell utforming» har blitt konkretisert gjennom TEK 10 ser vi følgende: Den juridiske avgrensingen «universell utforming av byggverk» avgrenser et relativt bredt konkret alle, som sikrer en bred krets mennesker tilgang til publikums- og arbeidsbygninger. Den juridiske avgrensingen «tilgjengelig boenhet» avgrenser et noe smalere konkret alle, som inkluderer rullestolbrukere og til en viss grad svaksynte, og har en mer begrenset ambisjon om å sikre «tilgjengelighet» for disse andre grupper enn rullestolbrukere.

Det som er vunnet med TEK 10 er imidlertid ganske klart: TEK 10 gjelder alle nye boliger, og sikrer en konkret bedring i tilgangen til disse, spesielt for rullestolbrukere. Men det er viktig å være klar over hvor avgrenset dette kravet er. Ut fra TEK 10 kan man bygge 
«tilgjengelige boliger» men som fortsatt kan være knøttsmå ettromsleiligheter nesten uten dagslys. Ut ifra TEK 10 må gangen og soverommet være store nok til at man kan snu seg rundt $\mathrm{i}$ dem, sittende $\mathrm{i}$ en rullestol. Man kan imidlertid komme seg rundt dette kravet om snusirkler ved at gangen og soverommet rett og slett droppes. ${ }^{12}$

\section{Refleksjoner: Boliger for uføre?}

Mange, og spesielt deler av byggnæringen, har kritisert TEK 10 for at kravene til «tilgjengelig boenhet» er unødig fordyrende og representerer en betydelig ekstrautgift for folk som ikke trenger slik tilgjengelighet. Dette fordi arealet må økes for de minste boligene for å gjøre dem salgbare (Kvinge, Langset, og Nørve 2012). Jon Hustad og Elin Ørjasæter fremsatte denne kritikken i TV-programmet «Harde Fakta». Kritikken ble tilsynelatende saklig tilbakevist av statssekretær Sandbakken ${ }^{13}$. Men denne tilbakevisingen ble, tilsynelatende like saklig, tilbakevist igjen, av Jon Hustad ${ }^{14}$.

I motsetning til Hustads argumentasjon om at «universell utforming» går for langt, argumenterer boligforskerne Jon Guttu og Lene Schmidt for det motsatte, nemlig at kravene «tilgjengelig boenhet» ikke går langt nok. I en bovaneundersøkelse har de undersøkt hvordan de nye små-leilighetene faktisk brukes (Schmidt and Guttu 2012). De viser at nye, små leiligheter er vanskelig nok å innrede for «vanlige» beboere, men at de er enda verre å innrede for funksjonshemmede, spesielt for rullestolbrukere. Disse brukerne trenger mer enn «snusirkler», de trenger også allment mer plass. Den «tilgjengelige boenheten» i TEK 10 er imidlertid intet vern mot slike små og rullestol-uvennlige leiligheter, hevder Schmidt og Guttu.

Så, går TEK 10 for langt i å sikre rettighetene til (noen) funksjonshemmede, eller går den ikke langt nok? Vel, bare for å ta det først, svaret er at den ikke går langt nok. Universell utforming er ingen betydelig ekstrautgift på boligmarkedet. Den generelle prisveksten fra 1992 til 2012 er på 48,3 \%. Prisveksten innen blokkleiligheter for samme periode er på $700 \% .{ }^{15}$ Det er økende tomtepriser og økende profitt hos utbyggerne som driver tomteprisene i dagens Norge, til dels fordi utbyggere holder tilbake tomter de kunne bygget ut ${ }^{16}$. I perioden 200-2012 utgjorde økningen av tomteprisene $48 \%$ av prisøkningen (Kvinge, Langset, og Nørve 2012, 8). For de minste leilighetene (ca. 1.9 mill i Oslo) vil universell utforming kunne utgjøre $8 \%$ prisøkning (Kvinge, Langset, og Nørve 2012, 69). Poenget vårt er heller dette: Enkelte boligutbyggere og enkelte høyrepopulistiske journalister har satt "vanlige folk" opp mot "funksjonshemmede", spesielt rullestolbrukere, og fått til å se ut som det er en interessekonflikt mellom dem.

Imidlertid er det også slik at selv om universell utforming faktisk har spilt en veldig liten rolle i prisutviklingen på boligmarkedet, så er ikke tilhengerne av universell utforming helt uten ansvar for at Hustad og co. har kunnet lage en slik interessekonflikt. Universell utforming og "planlegging for alle" var en gang formulert som et prinsipp som ville komme "alle" til gode, jamfør Carsten Boysens kongstanke: Bygger du for funksjonshemmede så bygger du for alle (Boysen, Hansen og Lange 1974).

Annonsekampanjen fra 2006 prøvde på sitt vis å bygge en allmenn allianse rund begrepet universell utforming. De ble stoppet av Handikapforbundet som følte at de gikk for langt i å usynliggjøre funksjonshemmede som gruppe. Det er mulig at annonsekampanjen gjorde det. Men på den annen side kan man argumentere for at denne kampanjen ikke gikk langt nok $\mathrm{i}$ å bygge en bred allianse. Boligforskerne Schmidt og Guttu hevder at den mangelen på krav om en generell «brukbarhet» i TEK 10 som i følge boligforskerne ville kommet barnefamilier og gamle til gode, gjør TEK 10 til en svak regulering, også - og spesielt - for bevegelseshemmede og svaksynte.

Altså, man kan spør seg følgende: Har mangelen på solidaritet og/eller strategisk alliansebygning med andre brukergrupper enn funksjonshemmede (gamle, unge, 
småbarnsforeldre, økonomisk svake) gjort at TEK 10 både mangler bred legitimitet og gitt funksjonshemmede et relativt dårlig vern? Og har mangelen på en slik allianse bidratt til å gi utbyggerinteressene i boligmarkedet for stor makt? Et eksempel illustrerer hva som kan stå på spill.

Hvis man er en rik rullestolbruker, eller har rike foreldre, så kan man kjøpe seg en stor enebolig på Oslos vestkant, med heis, store bad, store vinduer, og et kjøkken som er rommelig nok til å droppe skapene under kjøkkenbenken, men fortsatt har masse skapplass tilgjengelig. Hvis man er alenemor $\mathrm{i}$ en liten, gammel leilighet på Sagene eller Torshov (de finnes fortsatt!), og ett av hennes to barn havner i rullestol, så kan hun ikke gjøre det. Alenemoren kan ikke omsette sin lille leilighet til en stor rullestolvennlig en, uten å flytte langt ut av Oslo sentrum. Men hun har kanskje en jobb som knytter henne til Oslo sentrum, og for å klare tidsklemma mellom jobb, barnehage og skole er hun nødt til å bo sentrumsnært. Hun ville selvfølgelig fătt god hjelp fra velferdsstaten, gjennom NAV, og ville kunne klart seg ganske godt. Men det hun og hennes funksjonshemmede barn på denne måten kunne motta ville være økonomiske, organisatoriske og teknologiske scerordninger, gitt av at barnet var «funksjonshemmet». Poenget med Carsten Boysens «generelt hevede boligstandard», Husbankens kombinasjon av «minstestandard + livsløpsstandard» og Manneråkutvalgets «universelle utforming» var å bygge fysiske miljøer slik at man i størst mulig grad kunne unngå slike særordninger. Man burde unngå de særordningene som i kraft av å være nettopp særordninger opprettholdt stigmatiserende forskjeller heller enn å oppløse dem, og som Arne Skouen for lenge siden og med forakt omtalte som «veldedigheten» (Skouen and Gullvåg 1996).

Den brede brukbarheten som kunne komme alenemoren i indre Oslo til gode, kunne fulgt av at man inkluderte «universell utforming» i en bred sosialpolitisk strategi. Vi er fullt klar over at det å gjeninnføre Husbankens «minstestandard + livsløpsbolig» er hverken ønskelig eller mulig, og vår moral er ikke å skue tilbake på en antatt gyllen fortid. Poenget er bare å vise at utviklingen av «universell utforming» ikke bare er et framskritt, og at veien videre fram kanskje bør inkludere en reformulering av hva «universell utforming» som et bredt politisk prosjekt bør være.

\section{Lars Risan}

Seniorforsker

Norsk institutt for by- og regionforskning

E-post adresse: lars.risan@nibr.no

\section{Siri Nørve}

Seniorforsker

Norsk institutt for by- og regionforskning

E-post adresse: siri.norve@nibr.no 


\section{Referanser}

Aslaksen, F., Bringa, O. R., Bergh, S., \& Heggem, E. K. (1997). Universell utforming. Planlegging og design for alle. Oslo: Rådet for funksjonshemmede. Hentet fra http://home.online.no/ bringa/universell.htm

Bergh, S., \& Henriksen, G. (1998). Universell utforming i praksis. Oslo: Norges handikapforbund.

Bjørneboe, J. (1977). Boliger i bratt terreng (Bd. 11). Oslo: NBI.

Boysen, C. (1964). Boliger for eldre - Spesialboliger eller høynet boligstandard. Oslo: Boligdirektoratet.

Boysen, C. (1974). Boligen og de fysisk ufфre (Bd. 224). Oslo: NBI.

Boysen, C. (1978). De funksjonshemmede i boligmiljøet: forskning og erfaringer, oppgaver og perspektiver (Bd. 4). Oslo: Norges byggforskningsinstitutt.

Boysen, C., Hansen, R. A., \& Lange, T. (1974). Planlegg for bevegelseshemmede og du planlegger for alle (Bd. 228). Oslo: NBI.

Boysen, C., \& Lange, T. (1979). Om å gjфre vanlige boliger brukbare for bevegelseshemmede: tilpassing og merkostnader (Bd. 21). Oslo: NBI.

Boysen, C., Lange, T., \& Svennar, E. (1979). A 330.211 Tilpasning til bevegelseshemmede generelt. Norsk Byggforskningsinstitutt.

Breivik, J.-K. (2006). Døv identitetspolitikk - En særegen form for normalitet. I T. H. Eriksen \& J.-K. Breivik (Red.), Normalitet. Oslo: Universitetsforlaget.

Bringa, O. R. (1995). Veiviser : tilrettelegging av narmiljø for funksjonshemmede. Oslo: Kommuneforlaget.

Bringa, O. R. (1998). Veiviser til universell utforming. Oslo: Kommuneforl. : Rådet for funksjonshemmede.

Christophersen, J. (1990). Livslфpsboliger: fungerer eller feiler?: etterprøving av Husbankens regler (Bd. 70). Oslo: Instituttet.

Connell, B. R., Jones, M., Mace, R., Mueller, J., Mullick, A., Ostroff, E., ... Vanderheiden, G. (1997). The Principles of Universal Design. NC State University, The Center for Universal Design. Hentet fra NC State University, The Center for Universal Design

Cronberg, T. (1977). Funktionskrav i byggbestämmelser (Bd. R16:1977). Stockholm: Statens råd för byggnadsforskning.

Deltasenteret. (2006). Vi har en plan - om å skape et samfunn for alle. Arbeids- og inkluderingsdepartementet og Miljøverndepartementet.

DIFI. (2010). Statlig styring av kommunene. Rapport. Hentet 25. april 2013, fra http://www.regjeringen.no/nb/dep/krd/dok/rapporter_planer/rapporter/2010/Statlig-styring-avkommunene.html?id=601839.

Eriksen, T. H., \& Breivik, J.-K. (2006). Normalitet. Oslo: Universitetsforlaget.

Findeli, A. (2001). Rethinking Design Education for the 21st Century: Theoretical, Methodological, and Ethical Discussion. Design Issues, 17(1), 5-17. doi:10.1162/07479360152103796

Gulbrandsen, O. (1975). Om funksjonshemmede (Bd. 233). Oslo: NBI.

Guttu, J. (2003). «Den gode boligen»: fagfolks oppfatning av boligkvalitet gjennom 50 år. Arkitektur- og designhøgskolen i Oslo, Oslo.

Hanssen, M. B. (2010). Diskriminerings- og tilgjengelighetsloven - universell utforming - ikke godta diskriminering. Oslo: Norges handikapforbund.

Haug, E. (2001). Kommunal boligpolitikk. Oslo: Norges handikapforbund.

Haug, E., \& Aslaksen, F. (1998). Tilgjengelige uteområder. Oslo: Norges handikapforbund.

Heggem, E. K., \& Dobloug, M. (2000). Inspirasjon. Oslo: Norges handikapforbund.

Henriksen, G. (2007). Hva er universell utforming? Oslo: Norges handikapforbund.

Henriksen, G., \& Huvenes, R. (2008). Universell utforming - Hvordan kan vi påvirke? [Oslo]: Norges handikapforbund. 
Imrie, R. (2012). Universalism, universal design and equitable access to the built environment. Disabil Rehabil Disability and Rehabilitation, 34(10), 873-882.

Kommunal- og regionaldepartementet. (2010). Byggteknisk forskrift - TEK 10. Oslo: Norsk byggtjenestes forlag.

Lange, T., \& Ringnes, C. (1985). A 330.211 Livslфpsboliger. Norsk Byggforskningsinstitutt.

Miljøverndepartementet. (1998). Planlegging for alle (Veiledninger og brosjyrer). Miljøverndepartementet.

Miljøverndepartementet. (2007). Universell utforming. Begrepsavklaring (Rapport). Hentet fra http://www.regjeringen.no/nb/dep/md/dok/rapporter_planer/rapporter/2007/t-1468-universellutforming.html?id=493083.

Mumford, L. (1956). For Older People: Not Segregation But Integration. Shreveport: F.W. Dodge Corporation.

Myrdal, S. (2005). Fokus på skolebygg. Oslo: Norges handikapforbund.

Nersveen, J. (2009). Kontraster - farger - belysning: et fors $\phi k$ på å kategorisere hjelpetiltak med hensyn på universell utforming og svaksynte. Oslo: Norges blindeforbund.

NOU. (2001). NOU 2001: 22, Fra bruker til borger: en strategi for nedbygging av funksjonshemmende barrierer. Oslo: Statens forvaltningstjeneste. Informasjonsforvaltning.

NOU. (2003). NOU 2003: 24 Mer effektiv bygningslovgivning. Kommunal- og. Hentet fra http://www.regjeringen.no/nb/dep/krd/dok/nouer/2003/nou-2003-24.html?id=147997.

NOU. (2005a). NOU 2005: 12 Mer effektiv bygningslovgivning II. Kommunal- og regionaldepartementet.

NOU. (2005b). NOU 2005: 8, Likeverd og tilgjengelighet. Justis- og beredskapsdepartementet. Hentet fra http://www.regjeringen.no/nb/dep/jd/dok/nouer/2005/nou-2005-8.html?id=390520.

Nørve, S. (2009). Boligkvalitet og kommunal planlegging (Bd. 2009:8). Oslo: NIBR.

Reiersen, E., Thue, E., \& Jensen, L.-A. (1996). De tusen hjem: Den norske stats husbank 1946-96. Oslo: Ad notam Gyldendal.

Ryan, J. (2006). A Ragged Edge Online: Disability Discrimination -- Alive and Well in NYC. Ragged Edge Online. Hentet 13. juni 2013, fra http://www.raggededgemagazine.com/departments/reflections/000910.html.

Schmidt, L., \& Guttu, J. (2012). Små boliger: universell utforming, bovaner og brukskvalitet (Bd. 2012:1). Oslo: NIBR.

Seierstad, S. H., Jacobsen, S. F., \& Bringa, O. R. (1981). Livslфpsboligen: redegjørelse for tilgjengelighetskrav ved generell boligbygging. Oslo: Norges handikapforbund.

Skouen, A., \& Gullvåg, E. W. (1996). En journalists erindringer. Oslo: Aschehoug.

Slagstad, R. (1998). De nasjonale strateger. Oslo: Pax Forlag.

Steinfeld, E., \& Maisel, J. (2012). Universal Design: Creating Inclusive Environments (1. utg.). Hoboken, N.J.: John Wiley \& Sons.

Sæterdal, A., \& Hansen, T. (1969). Ammerud 1: planlegging av en ny bydel (Bd. 58). Oslo: Instituttet.

TEK97. (1997). DSB: Forskrift om krav til byggverk - TEK. Hentet 30. oktober 2012, fra http://oppslagsverket.dsb.no/content/arkiv/plan-bygg/forskrift-om-krav-til-byggverk/.

Tøssebro, J. (2010). Hva er funksjonshemming. Oslo: Universitetsforlaget. 


\footnotetext{
${ }^{1}$ Prosjektet er finansiert av Husbanken. Prosjektmedarbeiderne har bestått av NIBR-forskerne Erik Henningsen, Siri Nørve og Lars Risan. Underveis har disse forskerne intervjuet og snakket med en rekke personer innenfor feltene funksjonshemming- og boligpolitikk. Vi takker også Jon Guttu, Olav Rand Bringa, Tore Lange for mange konstruktive innspill.

${ }^{2}$ I et prosjekt som løp i perioden 1998-2001 brukte også Miljøverndepartementet «planlegging for alle» som synonymt med universell utforming, men sannsynligvis uten å kjenne Boysens tekster (Miljøverndepartementet 1998).

${ }^{3}$ På et ennå mer konkret nivå diskuterer han designdetaljer, så som hvor høye og lave kjøkkenskap bør være for å kunne brukes av eldre.

${ }^{4}$ Begrepet «arbeiderpartistaten» stammer fra Slagstad (Slagstad 1998). Selv om denne epoken i stor grad var styrt av Arbeiderpartiet, så var den større enn AP, og kjennetegnet av at også de borgerlige partiene videreførte dens politikk, da de satt i regjering.

${ }^{5}$ I 1992 finansierte Husbanken neste alle nybygde boliger. I 2008 er Husbankens andel av nyboligfinanisieringen sunket til 18,5\% Kilde: SSBs byggearealstatestikk og Husbanken.

${ }^{6} \mathrm{Se}$ http://biblioteket.husbanken.no/arkiv/dok/Hist/hb7b1-3-1994.pdf

${ }^{7}$ Laget av Husbanken, Kommunal or regionaldepartementet og Statens byggtekniske etat. Vi har ikke nøyaktig publiseringsdato, da vår kopi er av det opprinnelige pdf-dokumentet.

${ }^{8}$ «Universell utforming. Innledning, 01.03.2006», Norges Handikapforbund.

${ }^{9}$ Funksjonskrav setter krav til resultatet, eller funksjonen, uten å angi måten resultatet skal oppnås på.

10 TEK 10: § 2-1. Verifikasjon av funksjonskrav. (1) Der ytelser er gitt i forskriften, skal disse oppfylles. (2) Der ytelser ikke er gitt i forskriften, skal oppfyllelse av forskriftens funksjonskrav verifiseres enten, a) ved at byggverk prosjekteres i samsvar med preaksepterte ytelser, eller b) ved at byggverk prosjekteres i samsvar med ytelser verifisert ved analyse som viser at forskriftens funksjonskrav er oppfylt.

${ }^{11} 5$ paragrafer spesifiserer detaljer som ikke gjelder rullestolbruk. Disse spesifiserer detaljer i lysforhold for svaksynte (TEK 10, § 12-4, § $12-16, \S 12-16, \S 12-17$, og § 12-18).

${ }^{12}$ Kommunale reguleringsplaner kan imidlertid stille større krav til størrelse på leiligheter enn det TEK 10 gjør.

${ }^{13}$ Dag-Henrik Sandbakkens svar til "Harde Fakta".

${ }_{14}^{14}$ Harde Faktas svar til Sandbakken.

${ }^{15} \mathrm{Se}$ SSB http://www.ssb.no/bpi/ og http://www.ssb.no/priser-og-prisindekser/statistikker/kpi.

${ }^{16}$ Se f.eks. http://www.hegnar.no/personlig_okonomi/article739600.ece.
} 